\title{
Contribution of Good Agricultural Practices to Soil Biodiversity
}

\author{
Beata Houšková1 ${ }^{\circledR}$, Rastislav Bušo² ${ }^{2}$ Jarmila Makovníková ${ }^{3}$ (i) \\ ${ }^{1}$ National Agricultural and Food Centre/Soil Science and Conservation Research Institute, Bratislava, Slovakia \\ ${ }^{2}$ National Agricultural and Food Centre/VÚRV, Pieštany, Slovakia \\ ${ }^{3}$ National Agricultural and Food Centre/Soil Science and Conservation Research Institute, Banská Bystrica, Slovakia \\ Email: beata.houskova@nppc.sk
}

How to cite this paper: Houšková, B., Bušo, R. and Makovníková, J. (2021) Contribution of Good Agricultural Practices to Soil Biodiversity. Open Journal of Ecology, $11,75-85$.

https://doi.org/10.4236/oje.2021.111007

Received: November 22, 2020

Accepted: January 16, 2021

Published: January 19, 2021

Copyright $\odot 2021$ by author(s) and Scientific Research Publishing Inc. This work is licensed under the Creative Commons Attribution International License (CC BY 4.0).

http://creativecommons.org/licenses/by/4.0/

\begin{abstract}
At present time when climate change has negative effect on soil moisture and can decrease significantly the productivity, good agricultural practises have a high importance via their direct influence on soil properties, regimes and biodiversity. Objectives of this study have been focused on the assessment of good agricultural practises in different soil cultivation types: conventional, minimum till, mulch, no-till and organic farming. Method used was based on two case study areas where organic and/or minimal farming systems have been applied. As a control, we chose soil with traditional cultivation. In organic farm, we evaluated earthworms; their amount and status and in farm with different types of cultivation we evaluated the microbial activity to assess the biodiversity conditions. Basic soil properties and soil structure have been set to be able to assess the influence of good agricultural practises on soil environment. Our study shows positive effect of these practises on soil moisture content, biodiversity and soil structure stability. These findings can be used for further studies determining the ways of soil cultivation in harmony with nature-in sustainable way.
\end{abstract}

\section{Keywords}

Good Agricultural Practices, Soil Biodiversity, Earthworms, Microorganisms, Soil Enzymes, Organic Farm, Soil Moisture

\section{Introduction}

Soil as a complex system is an important part of environment. It acts as a reactor where many different processes between organic and inorganic phases occur. 
Soil biodiversity, representing the variety of living organisms belowground, is an important soil health indicator. In general, soil biodiversity is directly influencing the main soil property, which is soil fertility. In 1989, the World Wide Fund for Nature [1] defined biodiversity as "the wealth of life on Earth, millions of plants, animals and microorganisms, including the genes they contain, and as complex ecosystems that create the environment'. Biodiversity is affected by altitude, climate, relief, water availability, bedrock, soil but also human intervention. Biodiversity is represented at three basic levels as genetic (gene variability within a population or a whole species), generic (diversity at species level) and ecosystem (diversity at the level of communities and ecosystems). It is a very sensitive system highly dependent on its individual components, and disruption of one of them can lead to the extinction of a number of other components. This negative tendency can be observed also in soil. Biodiversity in agricultural land in Europe is threatened. Amount and the diversity of animal species is declining significantly. It is the result of the number of causes. Among the most striking are the intensification of agricultural production, the use of pesticides, the ploughing of field boundaries and the cultivation of monocultures in large areas. Since 1990, populations of birds and meadow butterflies-which are a good indicator of changes-have fallen by more than 30\% [2]. Biodiversity contributes to enhanced ecosystems, such as ecosystem stability and productivity, and improved nutrition and human health [3]. The higher the soil biodiversity, the better the soil fertility. Conservation and/or increasing soil fertility is extremely important because soil is a key element of the agroecosystem. Its biological activity, which is related to the processes occurring therein, can be greatly affected by anthropogenic interventions. In plenty of works it is also stated that in agricultural areas, conventional intensive farming practices have led to a significant decline in the biological diversity of soils [4]. It is caused by the use of fertilisers as well as pesticides. Excess of especially $\mathrm{N}$ fertilisers induces decrease of plant's metabolites, which contribute to the stability of soil structure [5], thus the stability of soil aggregates is decreased together with elimination of soil metabolites. Pesticides have negative effect on soil micro and macrofauna, e.g. earthworms. Many biochemical reactions in this environment are dependent or influenced by the presence of soil enzymes [6]. The soil enzymatic activity reflects the activity of microorganisms, controls the release of plant nutrients and the growth of microorganisms [7]. Enzymes can be used as indicators of soil quality [8] [9] [10] [11] [12]. Soil sustainability can be evaluated using enzyme activities [13] and can give also direct information concerning soil biodiversity. Higher organisms like earthworms represent also soil biodiversity indicators. Earthworms constitute a significant share of soil organisms and, owing to their activity in soil, are referred to as "ecosystem engineers" [14]. The activities of earthworms have significant effects on various ecosystem functions such as soil structure, nutrient cycling processes, decomposition of organic matter [15]. Lumbricidae contribute to the development of specific soil properties by improving its structure and increasing the field capacity [16] [17]. Earthworms influence soil structure by cre- 
ating burrows, by bringing litter into the soil, fragmenting it and mixing it with humus and mineral soil, by homogenizing the soil [18]. Christensen and Mather [19] showed that earthworm number and biomass reflect both; natural soil parameters, e.g. sand content on one side and agricultural practices on the other side. They react very sensitively to soil degradation or sanation. Cultivation technologies, which lead to the increase of soil microbial activity and occurrence of earthworms, can be considered as good agricultural practices. As stated in the research of The Can Caesar-TonThat [20], the proportion of soil aggregating Gram-negative bacteria, represented predominantly by pseudomonads and Stenotrophomonas maltophilia, was higher under irrigated no-till type of soil cultivation for barley in comparison to the other soil cultivation managements. Amount of soil aggregating bacteria was the lowest in conventional soil cultivation practices under irrigation, lower than in soils without irrigation. From these results, it is clear that the type of soil cultivation has higher effect on the amount of bacteria contributing to the stability of soil structure than application or omitting of irrigation.

Main reasons for cultivation technologies development can be divided into the economical, ecological and technological. Economical reasons evaluate mainly savings of work and energy, reducing workload, lowering staffing and increased machine performance. Ecological reasons are complex and they are focused on climate change mitigation, soil structure restoration and soil degradation prevention and/or sanation [21]. They contribute directly to soil biodiversity conservation and/or improvement.

Humankind at present time came to the progressive conclusions concerning preservation of nature. It is not possible to exploit natural resources in a non-safety and sustainable way anymore, otherwise we will destroy ourselves. Several environmental movements at political and/or societal level started, e.g. Agenda 2030 [22] at global level. One of the newest at European level is the new Biodiversity Strategy to 2030 with the title "Bringing nature back into our lives" [23]. Concerning soil, the new biodiversity initiative opened the public discussion about new Soil strategy, which is its part. This initiative will update the current strategy (from 2006) to address soil degradation and preserve land resources aiming to achieve land degradation neutrality-LDN.

Our research has ambition to contribute to the efforts to improve the focus on soil from purely economic views also to the environmental and sustainable ones. Good agricultural practises and organic farming provides practical conditions for farmers to use their soils in sustainable way and in a way, which cannot only preserve soil properties but also improve them from economical as well as environmental point of view.

\section{Material and Methods}

Soil properties and biodiversity have been studied on two farms: organic farm Agrokruh and experimental farm Borovce. 


\subsection{Organic Farm Agrokruh (Figure 1)}

The soil cultivation is provided in spirals and individual fields have circle shape. This cultivation is based on low soil surface disintegration without turning the soil layers and without heavy machinery and artificial fertilizers. It is realized by a rotating arm fixed in the middle of the field. Soil cultivating tool is mounted on a chain and is guided along the arm. It is possible to fix interchangeable tools that can serve as a spade, rotary tiller, and seeder or for drip irrigation. The circular fields are located side by side and one working arm can be easily moved to an adjacent field. On this farm, vegetables are cultivated. According to World Reference Base for Soil Resources, WRB, 2014 [24], studied soil belongs to soils with little or no profile differentiation. Soil type is calcaric Fluvisol. According to the texture, soil is medium heavy.

Measurements provided were soil structure-stability of soil aggregates in water according to Baksajev (in [25]) and earthworms' presence (number) and status (size and weight).

As a control served the field with conventional cultivation, soil structure was evaluated as agronomically valuable soil structure (aggregates between 0.5 - 3 $\mathrm{mm}$, in \%) and as a coefficient of soil structure (Cst) calculated from aggregates of different size according to the formula:

$$
C s t=a /(b+c)
$$

where:

$$
\begin{aligned}
& a \text {-aggregates size between } 0.25-7 \mathrm{~mm} \\
& b \text {-aggregates size }>7 \mathrm{~mm} ; \\
& c \text {-aggregates }<0.25 \mathrm{~mm} \text {. }
\end{aligned}
$$

\subsection{Experimental Farm Borovce (Figure 2)}

The different cultivation practises have been applied here: conventional cultivation, minimum tillage, mulch and no-till with crop rotation: corn maize-winter wheat-spring barley-soya been. Influences of these types of cultivation on soil microbial activity and water content in soil profile have been studied.

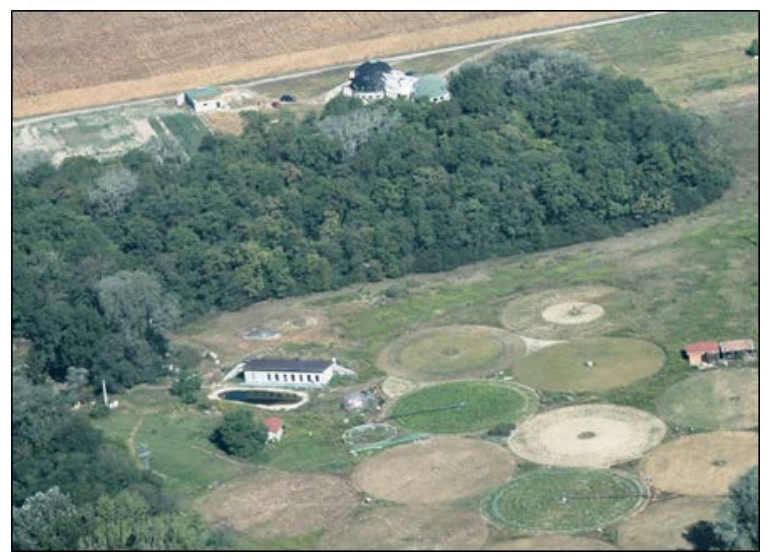

Figure 1. Biofarm Agrokruh. 


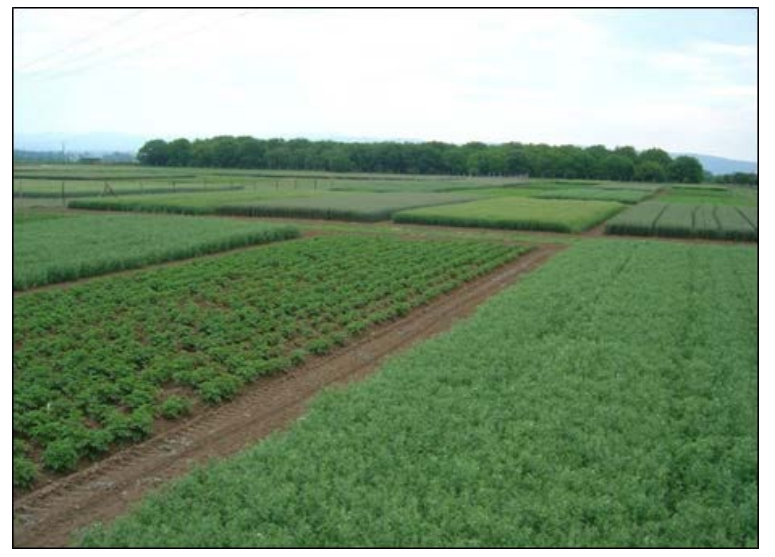

Figure 2. Experimental farm, Borovce.

Measurements provided were soil microbial activity expressed as production of $\mathrm{CO}_{2}$ in soil and as dehydrogenasis activity. Soil dehydrogenasis was measured according to the method described by Lenhard [26] and determined colorimetrically on a T60 UV/Visible. Soil moisture was evaluated to the depth of $1 \mathrm{~m}$ of soil profile by gravimetric method. Soil type belongs according to WRB, 2014 also to the soils with little or no profile differentiation. Soil type is Eutric Cambisol, medium heavy.

\section{Results and Discussion}

\section{Organic farm Agrokruh}

Coefficient of soil structure is higher in the soil from Agrokruh in the whole profile in comparison with soil with traditional cultivation. In varies according to the depth; from 1.8 for Agrokruh in the depth $0-20 \mathrm{~cm}, 2.3$ in $20-40 \mathrm{~cm}$ to 5 in the depth $40-60 \mathrm{~cm}$. For conventional cultivation it is: 1.6 in the depth $0-20$ $\mathrm{cm}, 0.9$ in $20-40 \mathrm{~cm}$ to the 1.7 in the depth of $40-60 \mathrm{~cm}$. Amount of agronomical valuable structure was the highest on biofarm and varies from $42 \%$ in the depth $0-20 \mathrm{~cm}, 55 \%$ in $20-40 \mathrm{~cm}$ to $69 \%$ in the depth $40-60 \mathrm{~cm}$. In comparison the traditional cultivation shows $40 \%$ in the depth of $0-20 \mathrm{~cm}, 31 \%$ in $20-40 \mathrm{~cm}$ and $47 \%$ in the depth of $40-60 \mathrm{~cm}$. Amount of microaggregates $(<0.25 \mathrm{~mm})$ shows that soil with traditional cultivation has the highest portion of such aggregates in the depth from 20 to $40 \mathrm{~cm}$. All these results can be evaluated as lower aggregates stability, which is direct effect of ploughing in comparison with the soil on organic farm, which is cultivated without ploughing.

Our results showed that land use connected with specialised management practices directly influence the spatial distribution as well as functioning ecology of earthworms in land. The earthworms density in soil monoliths from ecological farm recalculated per square meter shows that the amount of individuals was (average 2017-2018 year) 249 - 246 - 7 for 5 years ecological farming, 3 years ecological farming and conventional farming respectively. Ploughing contributes to a reduction in the population size and diversity of species of earthworms, as it physically disturbs the environment of earthworms and causes mechanical 
damage to earthworms, especially epigeic and anecic ones [27]. These conclusions were clearly confirmed also in our study. In organic farm, where the amount of earthworms' individuals exceeds several times the respective number in conventional soil cultivation, the soil is not ploughed, not turned, just cultivated by spade.

Concerning biomass, these results show significant positive effect of organic farming on the amount of earthworms in comparison to conventional cultivation (Table 1). The biomass was the highest in 3 years ecological farming comparing with 5 years. The biomass in conventional cultivation field was again significantly lower in comparison to the organic farm fields.

\section{Experimental farm Borovce}

Microbial activity expressed as $\mathrm{CO}_{2}$ productivity and dehydrogenase activity shows positive effect of soil saving technologies-good agricultural practices on its development (Table 2, Figure 4).

Soil saving cultivation practises increase dramatically the $\mathrm{CO}_{2}$ productivity in comparison with conventional cultivation. The best results are in soil with mulch.

Dehydrogenase activity is an accelerator of biological oxidation of organic substances in soil. It is influenced by several soil factors as soil type, $\mathrm{pH}$ and organic carbon. According to Mucha [28] the dehydrogenase activity is influenced by complex of agrotechnical measures focused on increase of biological potential. This is in accordance with our findings. The dehydrogenase increases together with humus content, which can be visible from Figure 3 and Figure 4 respectively. In comparison with conventional cultivation was always higher for alternative technologies, where also the highest humus content was determined.

Table 1. Earthworms biomass in soil on organic farm and conventional cultivation practice $\left(\mathrm{g} \cdot \mathrm{m}^{-2}\right.$ of soil), Agrokruh.

\begin{tabular}{cccc}
\hline Earthworms biomass in $\mathrm{g} \cdot \mathrm{m}^{-2}$ & 2017 year & 2018 year & average \\
\hline ecological farming (5 years) & 44.69 & 66.59 & 55.64 \\
ecological farming (3 years) & 37.34 & 102.68 & 70.01 \\
conventional farming & 10.61 & 0 & 5.305 \\
\hline
\end{tabular}

Table 2. $\mathrm{CO}_{2}$ productivity in soil with different cultivation practices ( $\mathrm{mg} \cdot 100 \mathrm{~g}^{-1}$ of soil), Borovce.

\begin{tabular}{|c|c|c|c|c|c|}
\hline $\begin{array}{c}\text { Average } \\
2016-2018\end{array}$ & $\begin{array}{l}\text { Depth } \\
(\mathrm{cm})\end{array}$ & $\begin{array}{l}\text { Conventional } \\
\text { cultivation }\end{array}$ & $\begin{array}{l}\text { Minimum } \\
\text { technology }\end{array}$ & $\begin{array}{l}\text { Mulch } \\
\text { technology }\end{array}$ & No-till \\
\hline \multirow{3}{*}{ Spring sampling } & $0-10$ & 3.32 & 5.44 & 7.36 & 8.55 \\
\hline & $10-30$ & 3.67 & 2.59 & 2.81 & 4.21 \\
\hline & average & 3.50 & 4.02 & 5.09 & 6.38 \\
\hline \multirow{3}{*}{ Autumn sampling } & $0-10$ & 3.11 & 5.10 & 5.92 & 8.95 \\
\hline & $10-30$ & 3.35 & 2.97 & 3.49 & 4.40 \\
\hline & average & 3.23 & 4.04 & 4.71 & 6.67 \\
\hline
\end{tabular}


Concerning soil moisture, the increase in it was the highest in mulch type of cultivation (Figure 5) followed with minimum and no-till. Except the depth 0.10 - $0.20 \mathrm{~m}$ the mulch had higher soil moisture content in comparison with the other soil saving cultivation technologies. From the depth of $0.4 \mathrm{~m}$ the minimum till field had the second highest soil moisture content. It can be the reason of better soil permeability after minimum till in comparison with no-till. Soil moisture content was always the lowest in the field with conventional cultivation but this can be also influence of plants uptake as the yield was high here.

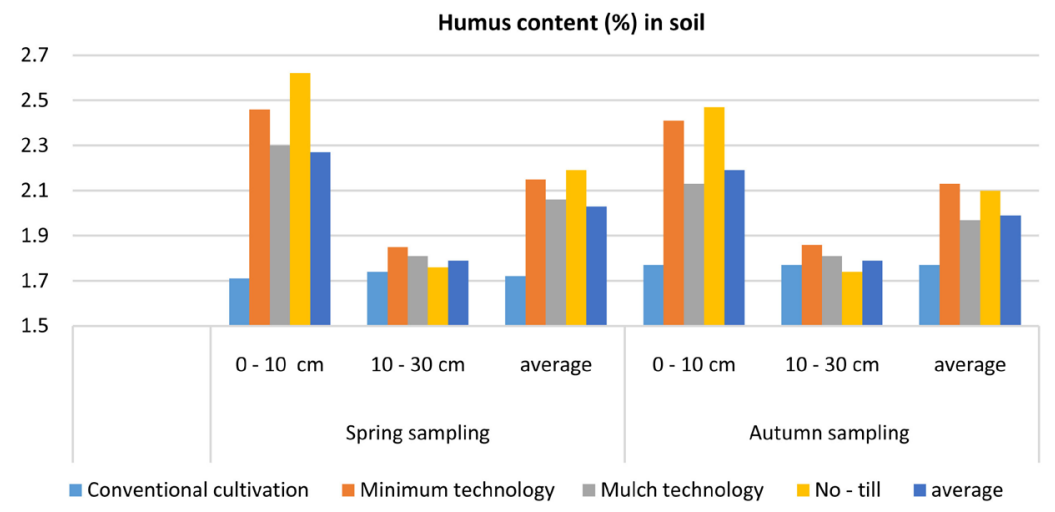

Figure 3. Influence of cultivation technologies on humus content in case study Borovce.

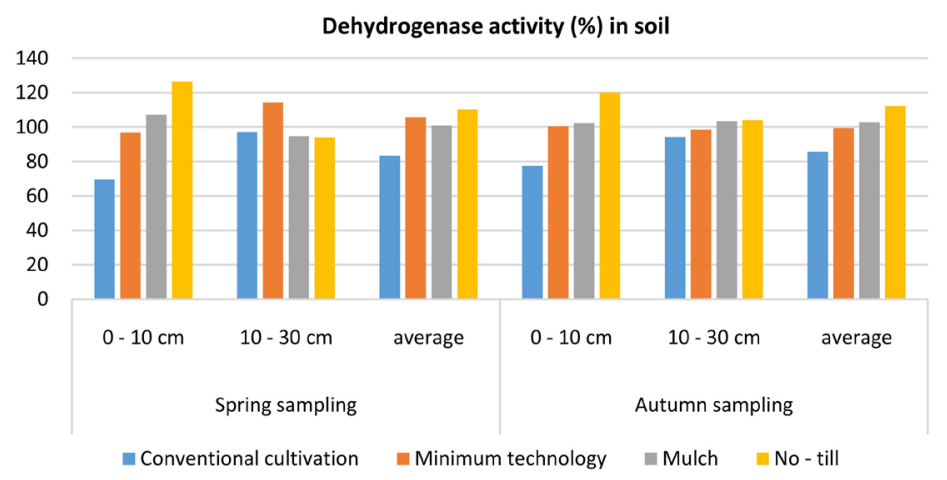

Figure 4. Dehydrogenase activity influenced by the type of soil cultivation, use case Borovce.

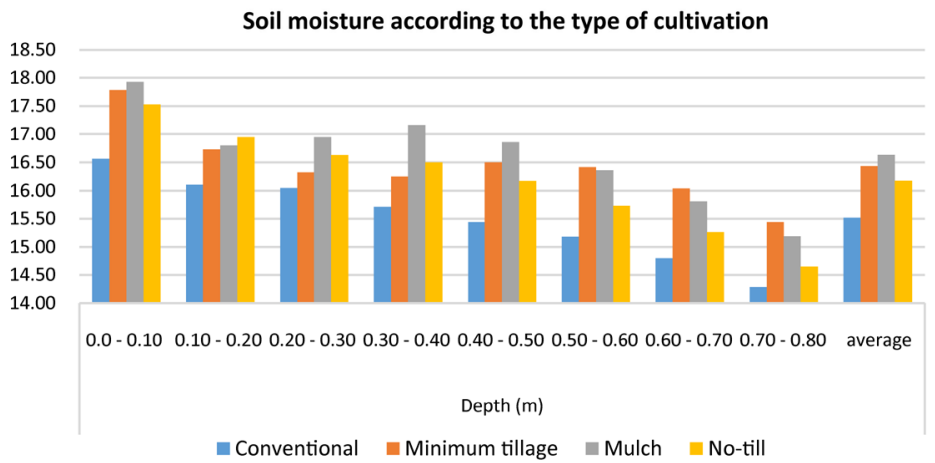

Figure 5. Effect on technology and depth on average soil moisture (\%) in 2016-2018, case study Borovce. 
The yield was not always the highest on soil with soil saving technologies applied (Figure 6). In case of winter wheat and corn the trend has been balanced but in case of soybean and mainly in case of spring barley the trend was declining for the yield average in soils with alternative cultivation in comparison with traditional one.
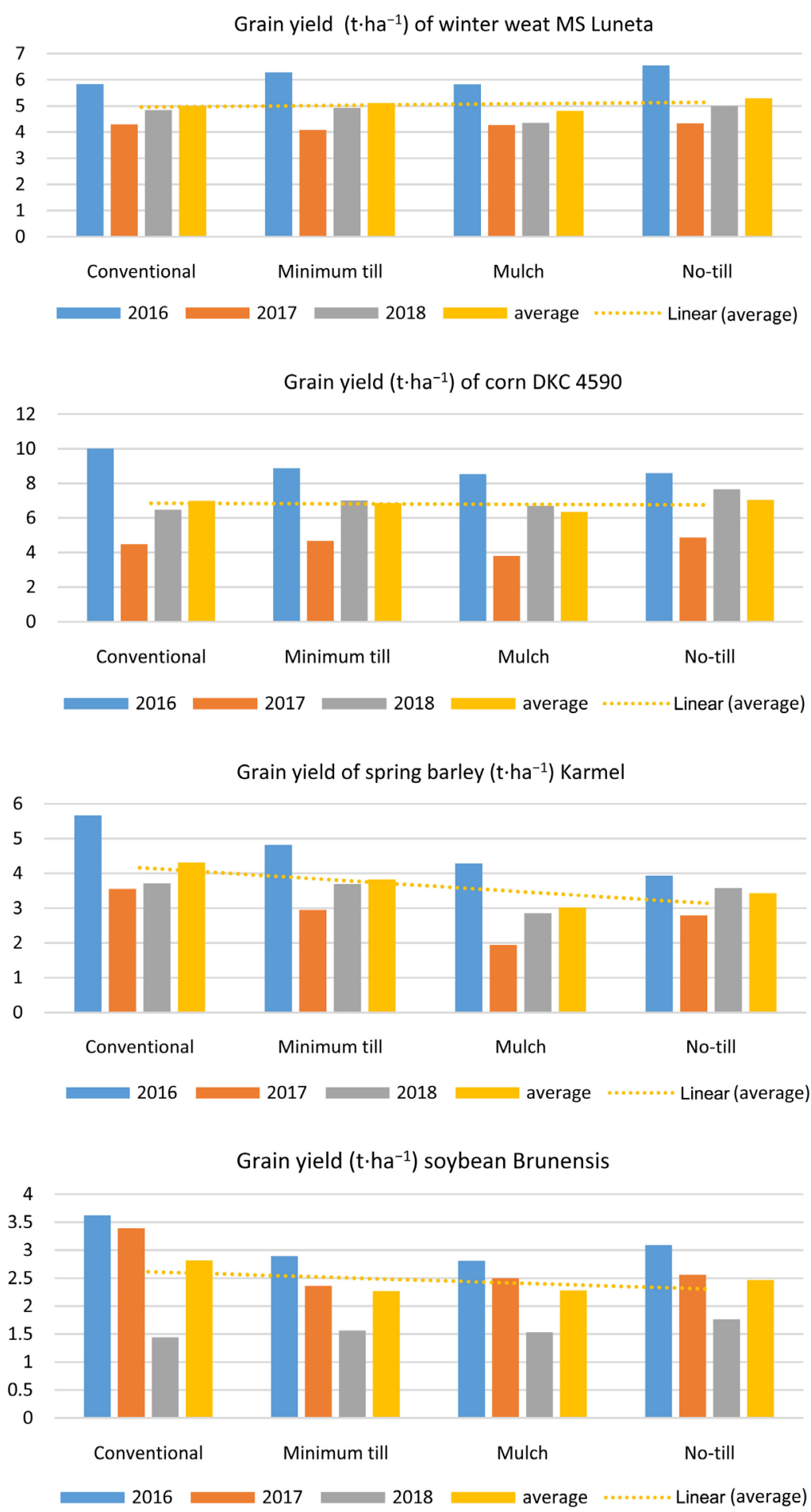

Figure 6. The yield on fields with conventional and soil saving cultivation. 
Anyhow, the positive environmental effect is considerable and it is possible to expect in prolonged time also its positive effect on soil fertility as well. At present time, it is important to consider the soil cultivation not only according to yields but also according to its influence on soil properties development from long timeline and according to the principles of sustainability.

Cultivation of soil without ploughing-turning the soil can have several positive effects. It influences soil aggregates stability and biodiversity-reflected as development of rich earthworms population. All these influences are complex processes including soil physical, chemical and biological regimes.

Dehydrogenase activity (DHA) is influenced by the presence of readily degradable organic substances but humus content as well. It reflects the level of microbiological settlement of the soil as well as the supply of soil with organic matter. It is part of the metabolism of all microorganisms. Even if several external agents can influence it, DHA can be used as a general indicator of soil biological activity. DHA increases together with $\mathrm{CO}_{2}$ production in soil and shows positive effect of soil saving cultivation technologies.

Increase of stable humus content is also complex, time demanding process. Soil as $\mathrm{CO}_{2}$ sink has an important role in climate change mitigation.

The yield on the farm in Borovce shows that not always the good agricultural practises have to lead immediately to the increase of soil fertility but from environmental point of view and with respect to cultivation of soil in sustainable way are these practises a good and achievable solution.

\section{Conclusion}

Good agricultural practices represented by minimum tillage, mulch, no-till and organic farm have influence on soil properties restoration, improvement and conservation. At present time when climate change has increasing effect, conservation of moisture in soil profile is very important and contributes directly to the sustainable use of natural resources. Soil biodiversity is crucial for soil properties improvement and good agricultural practices contribute directly or indirectly to the increase of soil biodiversity. Improvement of soil structure expressed as soil aggregates stability is direct evidence of good agricultural practices on soil sustainability. We can expect the yield increase also in soils with minimum tillage or no-till in comparison with traditional cultivation. Combination of both, soil structure and soil biodiversity can be used in the future research as a combined key performance indicator in the assessment of soil status when evaluating sustainability of soil use, influence of cultivation practises on soil properties and fertility and soil contribution to the sustainability of the surrounding environment. Soils with stable structure and rich biodiversity can contribute to climate change mitigation.

\section{Acknowledgements}

The authors acknowledge the Slovak Research and Development Agency for the 
financial support via contract APVV-APVV-15-0160: Elimination of degradation processes in soil by biodiversity restoring services.

\section{Conflicts of Interest}

The authors declare that they have no known competing financial interests or personal engagements that could create the reason to influence the work and results of the presented paper.

\section{References}

[1] World Wide Fund for Nature. https://www.worldwildlife.org/pages/what-is-biodiversity

[2] ECA (2020) Biodiversity on Farmland: CAP Contribution Has Not Halted the Decline. ECA Special Report Pursuant to Article 287(4), Second Subparagraph, TFEU. $58 \mathrm{p}$.

[3] Wall, D.H., Nielsen, U.N. and Six, J. (2015) Soil Biodiversity and Human Health. Nature, 528, 69-76. https://doi.org/10.1038/nature15744

[4] Briones, M.J.I. and Schmidt, O. (2017) Conventional Tillage Decreases the Abundance and Biomass of Earthworms and Alters Their Community Structure in a Global Meta-Analysis. Global Change Biology, 23, 4396-4419. https://doi.org/10.1111/gcb.13744

[5] Záhora, J. (2020) Pôda stráca kontrolu nad stabilitou pôdnych agregátov (Soil Losses Control over the Stability of Soil Aggregates). Naše Pole 1/2020, 14-16.

[6] Šarapatka, B. (1996) Vliv zemědělských systémů na aktivitu půdních enzymů. In Využitie integrovanej rastlinnej výroby $\mathrm{v}$ podmienkach Slovenska: Zborník zo seminára s medzinárodnou účastou. Nitra: Dom technniky ZSVTS, 1996, s. 48-51.

[7] Kovácsová, S. (2011) Enzymatická aktivita pôdnych mikroorganizmov (Enzymatic Activity of Soil Microorganisms). SPU Nitra, Slovakia.

[8] García, C. and Hernández, T. (2000) Research and Perspectives of Soil Enzymology in Spain. Tipografia, San Francisco, 352 p.

[9] Liu, K.L., Lai, C.M. and Helen, W. (2002) Soil Enzyme Activities as Indicators of Agricultural Soil Quality. Symposium 17 th World Congress of Soil Science, Vol. 1386, 1-6.

[10] Mikanová, O., Friedlová, M. and Šimon, T. (2009) The Influence of Fertilisation and Crop Station on Soil Microbial Characteristics in the Long-Term Field Experiment. Plant Soil Environment, 55, 11-16. https://doi.org/10.17221/326-PSE

[11] Mijangos, I. and Garbisu, C. (2010) Consequences of Soil Sampling Depth during the Assessment of the Effects of Tillage and Fertilization on Soil Quality: A Common Oversight. Soil \& Tillage Research, 109, 169-173. https://doi.org/10.1016/j.still.2010.05.001

[12] Šíša, R. (1993) Enzymová aktivita půdy jako ukazovatel její biologické aktivity. Rostlinná výroba, 39, 817-825.

[13] Senwo, Z.N., Ranatunga, T.D., Tazisong, I.A., et al. (2007) Phosphatase Activity of Ultisols and Relationship to Soil Fertility Indices. Journal of Food, Agriculture \& Environment, 5, 262-266.

[14] Jouquet, P., Dauber, J., Lagerlof, J., Lavelle, P. and Lepage, M. (2006) Soil Invertebrates as Ecosystem Engineers: Intended and Accidental Effects on Soil and Feedback Loops. Applied Soil Ecology, 32, 153-164. 
https://doi.org/10.1016/j.apsoil.2005.07.004

[15] Bacha, B. and Sahoo, S. (2019) Effect of Different Land Use Practices on Earthworm Abundance and Soil Properties. International Journal of Science and Research, 9, $1290-1294$.

https://www.ijsr.net/search_index_results_paperid.php?id=SR20323102830

[16] Zangerlé, A., Pando, A. and Lavelle, P. (2011) Do Earth-Worms and Roots Cooperate to Build Soil Macroaggregates? A Microcosm Experiment. Geoderma, 167-168, 303-309. https://doi.org/10.1016/j.geoderma.2011.09.004

[17] Schon, N.L., Mackay, A.D., Gray, R.A., Van Koten, C. and Dodd, M.B. (2017) Influence of Earthworm Abundance and Diversity on Soil Structure and the Implications for Soil Services throughout the Season. Pedobiologia, 62, 41-47. https://doi.org/10.1016/j.pedobi.2017.05.001

[18] Brown, G.G., Barois, I. and Lavelle, P. (2000) Regulation of Soil Organic Matter Dynamics and Microbial Activity in the Drilosphere and the Role of Interactions with Other Edaphic Functional Domains. European Journal of Soil Biology, 36, 177-198. https://doi.org/10.1016/S1164-5563(00)01062-1

[19] Christensen, O. and Mather, J.G. (1990) Dynamics of Lumbricid Earthworm Cocoons in Relation to Habitat Conditions at Three Different Arable Sites. Pedobiologia, 34, 227-238.

[20] Sainju, U.M., Caesar, A.J., West, M., et al. (2014) Soil-Aggregating Bacterial Community as Affected by Irrigation, Tillage, and Cropping System in the Northern Great Plains. The Soil Science, 179, 11-20. https://doi.org/10.1097/SS.0000000000000036

[21] Houšková, B., Makovníková, J., Šlinský, J. and Bušo, R. (2019) Ecological Farming: An Example of Sustainable Management. 9 th International Congress, Tirana, 26-28 September 2019, 55.

[22] The 2030 Agenda for Sustainable Development and the SDGs. https://ec.europa.eu/environment/sustainable-development/SDGs/index_en.htm

[23] (2020) Factsheet: EU 2030 Biodiversity Strategy. https://ec.europa.eu/commission/presscorner/detail/en/fs_20_906

[24] IUSS Working Group WRB (2015) World Reference Base for Soil Resources 2014, Update 2015. International Soil Classification System for Naming Soils and Creating Legends for Soil Maps. World Soil Resources Reports No. 106. FAO, Rome.

[25] Hraško, J., et al. (1962) Rozbory pôd (Soil Analyzes). Slovenské vydavatelstvo pôdohospodárskej literatúry. $342 \mathrm{p}$.

[26] Benefield, C.B., Howard, P.J.A. and Doreen, M.H. (1976) The Estimation of Dehydrogenase Activity in Soil. Short Communication. Soil Biology and Biochemistry, 9 , 67-70. https://doi.org/10.1016/0038-0717(77)90063-3

[27] Mazur-Pączka, A., Pączka, G., Kostecka, J., Garczyńska, M., Podolak, A. and Szura, R. (2019) Community Structure of Lumbricidae in Permanent Grassland and Arable Land. Journal of Ecological Engineering, 20, 1-6. https://doi.org/10.12911/22998993/102965

[28] Mucha, V. (1995) Dynamika enzýmovej aktivity v hnedozemných a čiernicových pôdach pod porastom vybraných plodín. II. Peroxidázy a polyfenoloxidázy. Polnohospodárstvo, 41, 412-420. 